Bull. Fac. Agric., Cairo Univ., 72: 1-11 (2021).

\title{
STUDY THE CHEMICAL AND TECHNOLOGICAL PROPERTIES OF SOME EGYPTIAN COTTON VARIETIES FERTILIZED WITH THREE DIFFERENT SOURCES OF NITROGEN AND CHEMICALLY TREATED
}

(Received: 25.1.2021)

\author{
By \\ Heba A. Mohamed and Rania M. Abdel- Twab \\ Cotton Institute Research, Agriculture Research Center, Giza, Egypt.
}

\begin{abstract}
This paper study and evaluate the technological and chemical properties of some Egyptian cotton fibers fertilized by three different compounds as source of nitrogen (Urea, Ammonium nitrate and Ammonium sulphate) and chemical treated (control, scouring and Mercerization). In our study three cotton fibers varieties were used [Giza 93 (Extra long stable), Giza 94 and Giza 95 (Long stable)] for 2019 season. The experimental design was split split-plot design with 3 replicates where nitrogen sources and chemical treated allocated in sub plots the verities were allocated in main plot, while the sub plots involved the nitrogen sources. The cotton fibers samples were subjected to chemical treatment (scouring pretreatment) at concentration $3 \%$ of Sodium hydroxide $(\mathrm{NaOH})$ and mercerization treatment at concentration $20 \%$ of Sodium hydroxide $(\mathrm{NaOH})$ and dying process by direct blue dye. The properties were examined fiber strength (g/tex), elongation \%, maturity degree, fineness diameter stiffens and Toughness as (technological properties) and sugar $\%$, wax $\%$, ash $\%$, moisture regain $\%$, accessibility $\%$, crystallinity percent, color strength (K/S) as (chemical properties). The results showed that, ammonium sulphate and mercerized samples were given high level value in technological properties fiber strength (gltex), elongation \% naturity degree and fineness diameter. Also, chemical properties were given high level value in moisture regain $\%$, accessibility $\%$, amorphous cellulose, color strength $(\mathrm{K} / \mathrm{S})$, toughness, fiber diameter and elongation \% while, caused decreases in crystallinity percent, strength (gltex) and stiffness .
\end{abstract}

Key word: Egyptian cotton fibers, nitrogenfertilization, mercerization, dyeing process.

\section{INTRODUCTION}

Cotton plays a leading role in the agriculture and industrial economy of the Arab Republic of Egypt. Cotton is characterized by the variation in shape of the fibers, each consisting of a single cell in the form of tube of cellulose which has collapsed, flattened and twisted as it is dried, (Collier, 1974).

Nitrogen is often the most limiting nutrient in agricultural production systems, where $\mathrm{N}$ additions are commonly required to achieve maximum yields. During the past century, the use of synthetic $\mathrm{N}$ sources have surpassed the use of organic sources (manures and legume rotations) in agricultural systems throughout most of the world (Smil, 2001); as a necessity to feed an increasing population. However, a renewed interest in use of manure has recently occurred due to the increasing cost of synthetic $\mathrm{N}$ sources and the need to deal with the large amounts of manure generated by concentrated animal production systems.

Efficient nitrogen $(\mathrm{N})$ management in cotton production is vital in order to attain adequate growth and development. Traditionally, $\mathrm{N}$ is provided to cotton plants through soil incorporated fertilizer applications at different stages during the growing season. However, soil incorporated $\mathrm{N}$ can experience a series of chemical alterations along with numerous loss mechanisms (leaching, volatilization and denitrification) that can render $\mathrm{N}$ unavailable for plant uptake. Furthermore, soil incorporated $\mathrm{N}$ has dealt with much inspection over the years for its role in many unfavorable environmental conditions. From early root and vegetative growth to active reproductive development, $\mathrm{N}$ is essential in every stage of cotton production and the requirement is substantial. James, 2014. 
One alternative includes the use of slowrelease $\mathrm{N}$ fertilizers that release their $\mathrm{N}$ content over a prolonged period of time through semipermeable coatings or by creating $\mathrm{N}$ compounds that exhibit varying degrees of resistance to chemical or microbial decomposition.

Ammonium nitrate can be applied directly into the soil surface (Brady and Weil, 2008) and can readily disassociate into $\mathrm{NH}_{4}{ }^{+}$and $\mathrm{NO}_{3}{ }^{-}$ (Havlin et al., 2005). However, due to national security concerns over its explosive capabilities, $\mathrm{NH}_{4} \mathrm{NO}_{3}$ usage has declined over the years and is even banned in a number of countries (Mengel and Kirkby, 1987). Ammonium sulfate is relatively easy to manage, can provide an ample supply of sulfur (S) to the plant and significantly decreases soil pH (Brady and Weil, 2008) which can be an asset in high $\mathrm{pH}$ soils.

Most recent developments in the cotton fiber properties are related to improvement in physical and chemical properties as well as Dyeability of modified cotton fibers to improve its properties as the demand for this natural fiber cannot be met by any other fiber (Patel 2005). In the fiber there will be progressively more and more randomness in the orientation of the molecules until in some places, there will be little or no indication of order. The ordered regions are known as crystalline and the disordered regions as amorphous. It is the simultaneous presence of both types of regions that gives fibers their unique chemical and physical properties.

Wimonrat et al. (2009) stated that, the scouring process represents the first step in the processing of natural fibers. It aims to remove dirt and impurities and preparing the fibers for further processing.

Mercerization of cotton materials increase the hydroscopic of the fiber and improve its dyeability. The structure properties, degree of polymerization and relative availability of $(\mathrm{OH})$ groups are also modified with mercerization, thus increasing the free hydroxyl groups $(\mathrm{OH})$. The change in cellulose physical properties are irreversible when the fibers swell with maximum water absorption; the cross-section of cotton fibers is increased under mercerization which causes swelling and facilitates penetrations of water sorption inside the fibers (Abd elaziz, 2005).

A new theory of mercerization as a physico-chemical change caused by sodium hydroxide solution forming dipole reaction of cellulose of the cotton fiber, and resulting in the formation of hydrogen bonds and salvation of cellulose (Ras, 1963).

It is well known fact that cotton fibers can be considerably modified in term of crystallinity, orientation of crystallites, tensile and mechanical properties by subjecting them to swelling treatments. However, the improvementproduced dose is not entirely the results of changes in crystallinity and orientation, but it could be attributed to the reduction of structure imperfections in cotton fibers during swelling and stretching process.

Orr et al., (1959) stated that has Fiber elongation at break on slack mercerization and mercerization, at the original length, a considerable variation in fiber bundle elongation at break, due to the different varieties of cotton used. And added that, the slack mercerized fibers showed considerably greater elongation. They also added that, the samples with low strength uniformity increase more in strength with slack mercerization than samples with high strength uniformity.

Direct dyes are commonly used on cotton fibers. These dyes are mixed in all purpose dyes along with the acid dyes. The color of direct dyes on cotton fibers is not bright in respect to other dyes. The wash fastness of these dyes is not very good. One more benefit of using direct dyes is that these can be used in the same dye bath with the acid dyes (Alliance Organics LLP, 2014).

The present study was planned to study the response of three different genotypes of cotton to different source of nitrogen and chemical treated.

\section{MATERIALS AND METHODS 2.1.MATERIALS}

Three commercial varieties of Egyptian cotton are: long stable (Giza 94 and Giza 95), and Extra-long stable (Giza 93) were used for the experiments at the Cotton Research institute where. The experimental design was laid out in a split- split plot based on a Randomized Complete Blocks Design arrangement with three replicaes according to Gomez and Gomez (1984). The main plots were assigned to the three cotton genotypes, and different nitrogen sources were allocated to subsub plots. Each sub plot consisted of 6 ridges with 3 meter length and $20 \mathrm{~cm}$ apart. The sub plot area was $14.4 \mathrm{~m}^{2}$ treatment included 27 treatment which were the combination of three 
genotypes (Giza 93, Giza 94 and Giza 95), three nitrogen sources (urea, ammonium nitrate and ammonium sulphate) and three chemical treated (control, scoring and Mercerization).

Table (1) shows the quality properties for three varieties of Egyptian cotton fibers are used in this study.

\subsubsection{Mercerization process}

The method of Al-Ashwat (1974) for mercerizing was followed. The fibers were immersed in sodium hydroxide $20 \%$, at room temperature for 2 minutes. This concentration was used because it is used by the industry, and then the Samples were washed with distilled

Table (1): The Egyptian cotton fiber quality properties.

\begin{tabular}{|c|c|c|c|c|c|c|c|c|c|c|}
\hline \multirow[t]{2}{*}{$\begin{array}{l}\text { Cotton } \\
\text { variety }\end{array}$} & \multirow[t]{2}{*}{ Color } & \multicolumn{2}{|c|}{ Value of color } & \multirow{2}{*}{$\begin{array}{c}\text { Maturity } \\
\text { ratio } \\
\text { (MR }\end{array}$} & \multicolumn{2}{|r|}{ Fiber length } & \multirow{2}{*}{$\begin{array}{l}\text { Total } \\
\text { reducing } \\
\text { sugars\% }\end{array}$} & \multicolumn{2}{|c|}{$\begin{array}{l}\text { Fiber strength\& } \\
\text { elongation }\end{array}$} & \multirow{2}{*}{$\begin{array}{l}\text { Fiber } \\
\text { perimeter } \\
\mu\end{array}$} \\
\hline & & $\begin{array}{l}\text { Brightness } \\
\text { (Rd) }\end{array}$ & $\begin{array}{c}\text { Yellowness } \\
(+b)\end{array}$ & & NHML & $\begin{array}{r}\text { Uniformity } \\
\text { Index \% }\end{array}$ & & $\begin{array}{r}\text { Strength } \\
(\mathrm{g} / \mathrm{tex})\end{array}$ & $\begin{array}{c}\text { Elongation } \\
\%\end{array}$ & \\
\hline Giza93 & Creamy & 66.4 & 11.5 & 0.94 & 37.5 & 88.1 & 0.18 & 49.0 & 6.4 & 43.52 \\
\hline Giza94 & White & 78.9 & 8.4 & 0.96 & 33.5 & 86.5 & 0.156 & 44.4 & 7.4 & 48.1 \\
\hline Giza95 & Creamy & 66.8 & 11.8 & 0.95 & 30.1 & 85 & 0.130 & 37.7 & 8.3 & 52.5 \\
\hline
\end{tabular}

\subsection{METHODS}

\subsubsection{Fertilization}

Two field experiments were carried out at the first week of April, for two seasons (2017 and 2018) to study the response of the three cotton varieties to fertilization by different nitrogen source in chemical and technological properties. The cotton varieties (Giza 93, Giza 94 and Giza 95) were fertilized with three different sources of nitrogen (three sources i.e. urea $(46.5 \%)$, ammonium nitrate $\left(\mathrm{NH}_{4} \mathrm{NO}_{3}\right)$ (33.5\%) and ammonium sulphate $\left(\mathrm{NH}_{4}\right)_{2} \mathrm{SO}_{4}$ $(20.5 \%)$. Nitrogen $(\mathrm{N})$ at the rate of $60 \mathrm{~kg}$ $\mathrm{N} / \mathrm{fed}$, as recommended, was split in two equal doses and side-dressed before the second and third irrigation from each source of nitrogen. Also, Potassium at the rate of $48 \mathrm{~kg} \mathrm{~K}_{2} \mathrm{O} / \mathrm{fed}$ as potassium sulphate was split and side-dressed before the second and third irrigation. On the other hand, Phosphorus was applied at the rate of $30 \mathrm{~kg} \mathrm{P}_{2} \mathrm{O}_{5} / \mathrm{fed}$ in the form super phosphate $\left(15.5 \% \mathrm{P}_{2} \mathrm{O}_{5}\right)$ was broadcasted during seed bed preparation in the form of ordinary super phosphate. All other Agricultural practices were applied according to the recommendations of the Agricultural Research and Experimental Station, Faculty of Agriculture, Cairo University, Giza, Egypt for cotton cultivation in the regions.

\subsubsection{Chemical Treatments}

\subsubsection{Scouring (pretreatment)}

In order to the elimination of non cellulosic material used sodium hydroxide $3 \%$ on weight of fibers (owf) using liquor ratio 1:30 at boiling for $90 \mathrm{~min}$ at $100^{\circ} \mathrm{C}$. Then washing with hot water and cold water and air dried at room temperature. This method was carried out according to Hebiesh et al. (1970). water. Residual alkali in the fibers was removed by immersion in $1 \%$ aqueous hydrochloric acid (HCL) for 5 min.then the samples were dried in an oven at $100^{\circ} \mathrm{C}$, for 60 minutes.

\subsubsection{Dyeing process}

The dyeing was carried out at $10 \%$ on weight of fibers (owf) with direct blue dye with $6 \%$ (owf) at 1:50 LR (material to liquor ratio), for $60 \mathrm{~min}$ at $50^{\circ} \mathrm{C}$ at neutral $\mathrm{pH}$. Then salt was added to the dyeing bath in three times, followed by adding the dye solution. Then the temperature was raised to boiling through 15 min, and the dyeing was continued at this temperature for $45 \mathrm{~min}$, finally the dyeing was stopped and the dyeing bath was cooled. Washing off: dyed samples were thoroughly rinsed with running water, then soap with a solution containing $5 \mathrm{~g} / \mathrm{l}$ nonionic detergent at $70^{\circ} \mathrm{C}$ for $15 \mathrm{~min}$. and finally, rinsing with water After washing the samples were left to be air dried. (Wang et al., 2007).

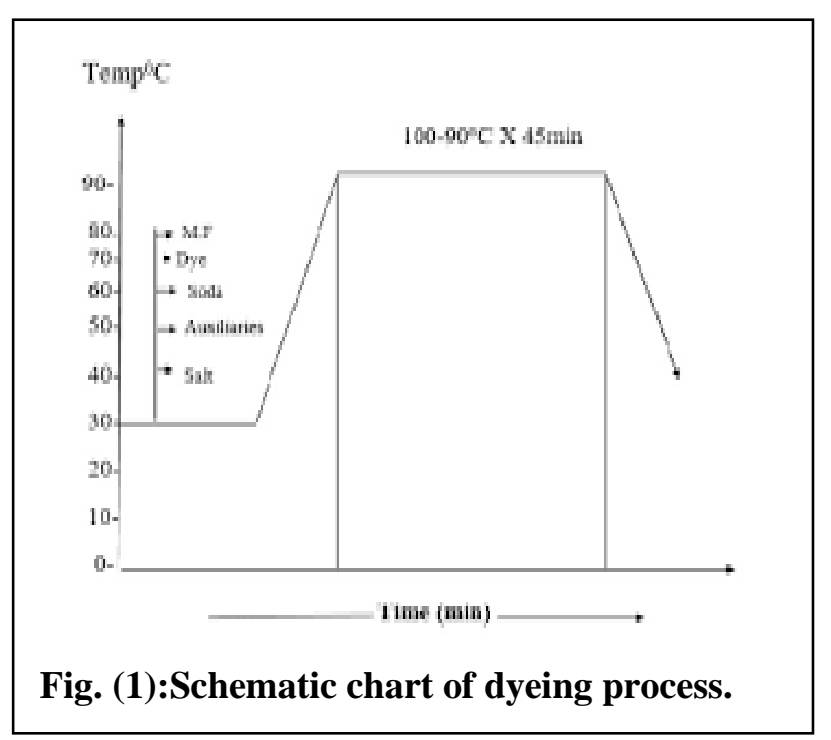




\subsubsection{Measurements}

\subsubsection{Technological properties}

\subsection{Strength and elongation}

The tensile strength (g/tex) and elongation (\%) were measured by Stelometer instrument at $1 / 8$ inch gauge length according to ASTM D1445- 1967, at the fiber testing Lab., Cotton Research Institute under constant conditions of temperature $\left(70^{\circ} \mathrm{C} \pm 2\right)$ and relative humidity $(65 \% \pm 2 \%)$.

\subsection{Fiber maturity and fineness diameter}

The Micromat instrument was used to determine micronaire reading, maturity ratio (MR), and fiber fineness and Diameter $\mu$, (ASTM -D; 2818-1982).

\subsection{Fiber toughness and stiffness}

From the value of flat bundle tenacity and elongation at 1/8 inch gauge length, the flat bundle toughness and stiffness were calculated according to the following equations (Grover and Hamby, 1960):

$$
\text { Fiber toughness }=\frac{\text { strength } \times \text { elongation } \%}{2}
$$

$$
\text { Fiber stiffness }=\frac{\text { strength }}{\text { Elongation } \%}
$$

\subsubsection{Chemical properties}

\subsubsection{Moisture regain \%}

The moisture regain of fibers was determined according to A.S.T.M. (1976) using the oven drying method and was calculated according to the Following equation:

$$
\text { Moisture regain } \%=\frac{W 0-W d}{W d}
$$

Where: W0: Weight of specimen as received, Wd: Weight of dry specimen

\subsubsection{Accessibility \%}

Accessibility percent was calculated by using the constant values according to Valentine, (1954). Moisture sorption= Moisture regain $\times 162 / 1800$.

Accessibility $\%=$ Moisture sorption $\times 100 / 1.53$.

\subsubsection{Cellulose crystallinity \%}

The use of iodine absorption method to measure crystallinity of cellulose fiber suggested by Schwertassak (1954) was adopted. A cotton fiber or yarn sample of $0.3 \mathrm{~g}$ was treated with $2 \mathrm{ml}$ iodine solution [5 $\mathrm{g}$ iodine and $40 \mathrm{~g}$ potassium iodide / $50 \mathrm{ml}$ distilled water]. A volume of $100 \mathrm{ml}$ saturated solution of sodium sulphate was added, and then left in darkness for an hour. The iodine remaining in the solution was determined by titration of $50 \mathrm{ml}$ with $\mathrm{N} / 50$ thiosulphate solution to which $50 \mathrm{ml}$ distilled water and $1 \mathrm{ml}$ starch solution $1 \%$ was added. In the meantime a blank on the original iodine solution was determined in a similar manner. Calculations were made as follows:

$$
\frac{(a-b) \times 2.04 \times 2.54}{0.3}
$$

Where: a: Volume (ml) of thiosulphate solution for blank

b: Volume (ml) of thiosulphate solution required for a cotton samples.

A ratio of $\mathrm{ml}$ of iodine adsorbed per $\mathrm{g}$ of cellulose gave a value for the amorphous fraction of cellulose; fiber crystallinity was obtained by subtracting the amorphous fraction percent from 100.

\subsubsection{Sugar $\%$ and wax $\%$}

The following method of Conrad (1944) was used for the determination of total wax and total soluble sugars in cotton fiber:

Place $5 \mathrm{~g}$. of well-cleaned fiber in a coarse timble in large soxhelts, then $250 \mathrm{ml}$ of $95 \%$ ethanol was added, continue the extraction for 6 hours, replace condenser and continue until ethanol has passed over and only 75-85 $\mathrm{ml}$ of liquid remain in extraction flask, then add $100 \mathrm{ml}$ of reagent grade chloroform to the seperatory funnel and mix. This should give a completely homogenous solution. Now add to mix $75 \mathrm{ml}$ water to cause mixing and separation two layers. Remove the chloroform from wax by evaporating, after the wax residue appears to be dry, cool and weight the beaker, the wax content. The levels of extraction consist of total soluble sugar measured according to (Smith et al., 1956) by using phenol/ sulphric acid method.

\subsection{Ash \%}

The ash of fibers was determined according to A.A.T.C.C. (1994). Using the oven drying method and was calculated according to the following equation:

$$
\text { Ash }=\frac{W a-W b}{W o-W b}
$$

Wa: weight of sample and gait before dried, $\mathrm{Wb}$ : weight of sample and gait after dried, and Wo: weight of gait before dried

\subsection{Color strength (K/S)}

The reflectance value of a specimen for the wave length of $400 \mathrm{~nm}-700 \mathrm{~nm}$ using spectrophotometer (Lambda 35, Perkin-Elmer, USA). The measurement was performed in accordance to Trotman, 1984. Using CIE color system coordinates. By using this reflectance value into the Kubelka Munk's equation color strength (K/S) can be determined using (Kubelka-Munk equation) 


$$
\mathrm{K} / \mathrm{S}=\frac{(1-R)^{2}}{2 R}
$$

Where, $\mathrm{R}=$ Reflectance of an incident light from the dyed material, $\mathrm{K}=$ Absorption, and $\mathrm{S}=$ Scattering coefficient of the dyed fabric.

Statistical analysis

Data were conducted statistically analyzed according to procedures out lined by Sendecor and Cochran (1981). The least significant differences (L.S.D) test at $50 \%$ level of significant was used to compare treatment means.

\section{RESULT AND DISCUSSION}

The data concerning the effect of chemical modification on technological (mechanical and physical) and chemical properties of three fertilized Egyptian cotton varieties by three different sources of nitrogen is discussed below.

\subsection{Mechanical Properties:}

\subsubsection{Strength (g/tex) and Elongation (\%)}

The results in Table (2) cleared that, there were significant differences among the three genotypes, nitrogen sources and chemical treatment in strength and elongation \%. Giza 93 fertilized with ammonium sulphate with control chemical treated was superior in strength while Giza 93 with ammonium sulphate with scouring chemical treated was superior in strength, and Giza 93 with ammonium sulphate and mercerization treated recorded the best value in Elongation \%. Fiber strength is the force required to break a standard bundle of cotton fibers. Strength measurements are reported in $g$ /tex. Table (2) showed that, the mechanical properties obtained for fiber tensile strength (g/tex) and elongation \%. Scouring and mercerization treatment led to a clear decrease in fiber strength which might be attributed mainly to the increase in spiral angle of the fiber due to its swelling De Boer, 1973).

On the other hand, it was found that slack mercerization of fibers caused a higher increase in elongation \%. This increase may be attributed to various factors including, the decrease in crystallinity of cellulose, the increase in the spiral angle, and the removal of morphological weak points in the structure of the fiber (Orr et al., 1959). Fertilizer $\mathrm{N}$ sources effects on fiber strength were highly variable. It is interesting to note that fiber strength with ammonium sulphate (AS) was highest and Urea (U) lowest, whether this was due to differences in varieties, environment or their interaction among years cannot be determined. Regardless of this variation in treatment effects among years, all strength measurements fell into the base or strong range and therefore would not have affected cotton value (Dexter et al.,2014).

\subsubsection{Toughness $(\mathrm{g} / \mathrm{tex})$ and Stiffness $(\mathrm{g} / \mathrm{tex})$}

The result in Table (3) showed that there were significant differences among the three genotypes, nitrogen sources and chemical treatment in toughness $(\mathrm{g} / \mathrm{tex})$ and stiffness (g/tex) where as Giza 93 fertilized with ammonium sulphate with control chemical

Table (2): Strength and elongation of cotton fiber as affected by the interaction among cultivars, nitrogen sources and chemical treatments.

\begin{tabular}{|c|c|c|c|c|c|c|c|}
\hline \multicolumn{2}{|c|}{ Treatments } & \multicolumn{3}{|c|}{ Strength $(g /$ tex $)$} & \multicolumn{3}{|c|}{ Elongation \% } \\
\hline \multirow{2}{*}{$\begin{array}{c}\text { Cultivars } \\
\text { (A) }\end{array}$} & \multirow{2}{*}{$\begin{array}{c}\text { Nitrogen } \\
\text { Sources (B) }\end{array}$} & \multicolumn{3}{|c|}{ Chemical Treatments (C) } & \multicolumn{3}{|c|}{ Chemical Treatments $(\mathbf{C})$} \\
\hline & & Control & Scouring & Mercerization & Control & Scouring & Mercerization \\
\hline \multirow{3}{*}{ Giza 93} & Urea (U) & 32.66 & 30.74 & 28.18 & 6.21 & 8.17 & 11.51 \\
\hline & $\begin{array}{l}\text { Ammonium } \\
\text { Nitrate (AN) }\end{array}$ & 32.94 & 31.46 & 29.34 & 6.97 & 8.30 & 11.69 \\
\hline & $\begin{array}{l}\text { Ammonium } \\
\text { Sulfate (AS) }\end{array}$ & 34.78 & 33.02 & 30.78 & 7.26 & 8.81 & 12.04 \\
\hline \multirow{3}{*}{ Giza 94} & Urea $(\mathbf{U})$ & 28.77 & 26.94 & 24.75 & 6.20 & 7.87 & 10.83 \\
\hline & $\begin{array}{l}\text { Ammonium } \\
\text { Nitrate (AN) }\end{array}$ & 29.48 & 27.66 & 25.36 & 6.57 & 7.95 & 11.23 \\
\hline & $\begin{array}{l}\text { Ammonium } \\
\text { Sulfate (AS) }\end{array}$ & 30.07 & 28.69 & 26.38 & 6.58 & 8.25 & 11.81 \\
\hline \multirow{3}{*}{ Giza 95} & Urea (U) & 26.74 & 24.39 & 22.46 & 6.07 & 7.42 & 11.77 \\
\hline & $\begin{array}{l}\text { Ammonium } \\
\text { Nitrate (AN) }\end{array}$ & 27.08 & 24.98 & 22.91 & 6.13 & 7.44 & 10.36 \\
\hline & $\begin{array}{l}\text { Ammonium } \\
\text { Sulfate (AS) }\end{array}$ & 27.65 & 25.64 & 23.88 & 6.17 & 8.52 & 10.38 \\
\hline \multicolumn{2}{|c|}{ L.S.D0.05 $(\mathrm{A} \times \mathrm{B} \times \mathrm{C})$} & \multicolumn{3}{|c|}{0.71} & \multicolumn{3}{|c|}{0.68} \\
\hline
\end{tabular}


Table (3): Toughness and stiffness of cotton fiber as affected by the interaction among cultivars, nitrogen sources and chemical treatments.

\begin{tabular}{|c|c|c|c|c|c|c|c|}
\hline \multicolumn{2}{|c|}{ Treatments } & \multirow{2}{*}{\multicolumn{3}{|c|}{$\begin{array}{c}\text { Toughness }(\mathrm{g} / \mathrm{tex}) \\
\text { Chemical Treatments }(\mathrm{C})\end{array}$}} & \multirow{2}{*}{\multicolumn{3}{|c|}{$\begin{array}{c}\text { Stiffness (g/tex) } \\
\text { Chemical Treatments }(C)\end{array}$}} \\
\hline \multirow{2}{*}{$\begin{array}{c}\text { Cultivars } \\
\text { (A) }\end{array}$} & \multirow{2}{*}{$\begin{array}{c}\text { Nitrogen } \\
\text { Sources (B) }\end{array}$} & & & & & & \\
\hline & & Control & Scouring & Mercerization & Control & Scouring & Mercerization \\
\hline \multirow[t]{3}{*}{ Giza 93} & Urea (U) & 101.41 & 125.57 & 162.18 & 5.26 & 3.76 & 2.45 \\
\hline & $\begin{array}{l}\text { Ammonium } \\
\text { Nitrate } \\
\text { (AN) }\end{array}$ & 114.80 & 130.56 & 171.49 & 4.73 & 3.79 & 2.51 \\
\hline & $\begin{array}{l}\text { Ammonium } \\
\text { Sulfate (AS) }\end{array}$ & 126.25 & 145.45 & 185.30 & 4.79 & 3.75 & 2.56 \\
\hline \multirow[t]{3}{*}{ Giza 94} & Urea (U) & 89.19 & 106.01 & 134.02 & 4.64 & 3.42 & 2.29 \\
\hline & $\begin{array}{l}\text { Ammonium } \\
\text { Nitrate } \\
\text { (AN) }\end{array}$ & 96.84 & 109.95 & 142.40 & 4.49 & 3.48 & 2.26 \\
\hline & $\begin{array}{l}\text { Ammonium } \\
\text { Sulfate (AS) }\end{array}$ & 98.93 & 118.35 & 155.77 & 4.57 & 3.44 & 2.23 \\
\hline \multirow[t]{3}{*}{ Giza 95} & Urea (U) & 81.16 & 90.49 & 116.57 & 4.41 & 3.29 & 2.16 \\
\hline & $\begin{array}{l}\text { Ammonium } \\
\text { Nitrate } \\
\text { (AN) }\end{array}$ & 83.00 & 92.93 & 118.67 & 4.42 & 3.36 & 2.21 \\
\hline & $\begin{array}{l}\text { Ammonium } \\
\text { Sulfate (AS) }\end{array}$ & 85.30 & 95.23 & 127.35 & 4.48 & 3.01 & 2.03 \\
\hline \multicolumn{2}{|c|}{ L.S.D0.05 $(\mathrm{A} \times \mathrm{B} \times \mathrm{C})$} & \multicolumn{3}{|c|}{1.24} & \multicolumn{3}{|c|}{0.22} \\
\hline
\end{tabular}

treated superior in toughness, while Giza 93 was ammonium sulphate with scouring chemical treated was superior in toughness $(\mathrm{g} / \mathrm{tex})$ and stiffness (g/tex), and Giza 93 with ammonium sulphate and mercerization treated scored the best value in toughness ( $\mathrm{g} / \mathrm{tex})$ and stiffness (g/tex). The results of fiber toughness of the investigated cotton varieties mercerized as well as the achieved increase as percentage of the control are shown in Table (3). Mercerization process increased fiber elongation as a whole and fiber strength in few cases, (Kamal 1980).It can be concluded that fiber stiffness decreases as a result of mercerization process, (Ahmed 1981).

\subsection{Physical Properties:}

\subsection{Fiber diameter and maturity $\%$}

Data in Table (4) reported that there were significant differences among the three genotypes, nitrogen sources and chemical treatment in fiber diameter and maturity \%, where Giza 93 fertilized with ammonium sulphate treated with control chemical was superior in toughness while Giza 93 with Ammonium sulphate treated,with scouring chemical was superior in fiber diameter and maturity \%, and Giza 93 treated treated with ammonium sulphate and mercerization scored the best value in fiber diameter and maturity \%,
Table (4) shows fiber fineness diameter that chemical modification scouring and mercerization result in increase in fiber diameter due to removing the outer wax layer of the cotton fiber, while fiber maturity showed that a decrease. This could be due to the swelling of fibers in $\mathrm{NaOH}$ which caused increase in spiral angle, and partially to the decrease in crystallinity, (Lawson et al., 1979, Shereen and Heba, 2019).

\subsection{Chemical Properties:}

3.3.1. Mositure regain $\%$ and Accessibility \%

The data in Table (5) indicated that the mercerization process caused an increase in moisture regain \% from 6.78 to 8.87 for Giza 93, from 6.80 to 9.06 for Giza 94, and from 6.77 to 9.13 for Giza 95 with (ammonium sulphate) treatment. This may be due to the changing in the structure of cellulose in cotton fibers and increase the percentage of amorphous cellulose and also increasing the free hydroxyl groups $(\mathrm{OH})$ which attract the water molecules. (AbdelAziz, 2001 and Abdel-Aziz (2015). Also, Mercerization process caused an increase in accessibility \% for all Egyptian cotton varieties. Because increase in amorphous cellulose, regains due to decrease in crystallinity present so increasing the free hydroxyl groups $(\mathrm{OH})$ due to increase accessibility $\%$. 
Table(4): Fiber diameter and maturity of cotton fiber as affected by the interaction among cultivars, nitrogen sources and chemical treatments.

\begin{tabular}{|c|c|c|c|c|c|c|c|}
\hline \multicolumn{2}{|c|}{ Treatments } & \multicolumn{3}{|c|}{ Diameter $\mu$} & \multicolumn{3}{|c|}{ Maturity \% } \\
\hline \multirow{2}{*}{$\begin{array}{l}\text { Cultivars } \\
\text { (A) }\end{array}$} & \multirow{2}{*}{$\begin{array}{c}\text { Nitrogen } \\
\text { Sources (B) }\end{array}$} & \multicolumn{3}{|c|}{ Chemical Treatments $(\mathrm{C})$} & \multicolumn{3}{|c|}{ Chemical Treatments (C) } \\
\hline & & Control & \begin{tabular}{|l|} 
Scouring \\
\end{tabular} & Mercerization & Control & Scouring & Mercerization \\
\hline \multirow[t]{3}{*}{ Giza 93} & Urea (U) & 16.44 & 16.89 & 17.51 & 75 & 69 & 63 \\
\hline & $\begin{array}{l}\text { Ammonium } \\
\text { Nitrate (AN) }\end{array}$ & 16.53 & 16.78 & 17.78 & 77 & 70 & 65 \\
\hline & $\begin{array}{l}\text { Ammonium } \\
\text { Sulfate (AS) }\end{array}$ & 16.61 & 16.90 & 17.83 & 80 & 75 & 70 \\
\hline \multirow[t]{3}{*}{ Giza 94} & Urea $(\mathbf{U})$ & 16.60 & 16.48 & 17.34 & 70 & 67 & 60 \\
\hline & $\begin{array}{l}\text { Ammonium } \\
\text { Nitrate (AN) }\end{array}$ & 16.49 & 16.73 & 17.53 & 74 & 70 & 65 \\
\hline & $\begin{array}{l}\text { Ammonium } \\
\text { Sulfate (AS) }\end{array}$ & 17.35 & 17.96 & 18.32 & 75 & 73 & 68 \\
\hline \multirow[t]{3}{*}{ Giza 95} & Urea (U) & 17.16 & 17.90 & 18.63 & 69 & 65 & 60 \\
\hline & $\begin{array}{l}\text { Ammonium } \\
\text { Nitrate (AN) }\end{array}$ & 17.54 & 17.94 & 18.65 & 70 & 70 & 65 \\
\hline & $\begin{array}{l}\text { Ammonium } \\
\text { Sulfate (AS) }\end{array}$ & 17.82 & 18.11 & 18.83 & 73 & 72 & 68 \\
\hline \multicolumn{2}{|c|}{ L.S.D0.05 $(\mathrm{A} \times \mathrm{B} \times \mathbf{C})$} & \multicolumn{3}{|c|}{0.28} & \multicolumn{3}{|c|}{0.14} \\
\hline
\end{tabular}

be due to variety and grade of some

Table (5):Moisture regain\% and accessibility of cotton fiber as affected by the interaction among cultivars, nitrogen sources and chemical treatments.

\begin{tabular}{|l|l|c|c|c|c|c|c|}
\hline \multicolumn{2}{|c|}{ Treatments } & \multicolumn{3}{c|}{ Moisture Regain \% } & \multicolumn{3}{c|}{ Accessbility \% } \\
\hline $\begin{array}{l}\text { Cultivars } \\
\text { (A) }\end{array}$ & $\begin{array}{l}\text { Nitrogen } \\
\text { Sources (B) }\end{array}$ & \multicolumn{3}{c|}{ Chemical Treatments (C) } & \multicolumn{3}{c|}{ Chemical Treatments (C) } \\
\cline { 3 - 8 } & Control & Scouring & Mercerization & Control & Scouring & Mercerization \\
\hline \multirow{7}{*}{ Giza 93 } & Urea (U) & 6.26 & 7.08 & 8.62 & 36.82 & 41.65 & 50.71 \\
\cline { 2 - 8 } & $\begin{array}{l}\text { Ammonium } \\
\text { Nitrate (AN) }\end{array}$ & 6.56 & 7.18 & 8.68 & 38.59 & 42.24 & 51.06 \\
\cline { 2 - 8 } & $\begin{array}{l}\text { Ammonium } \\
\text { Sulfate (AS) }\end{array}$ & 6.78 & 7.81 & 8.87 & 38.88 & 42.94 & 50.18 \\
\hline \multirow{3}{*}{ Giza 94 } & Urea (U) & 6.30 & 7.59 & 8.55 & 37.60 & 44.65 & 50.29 \\
\cline { 2 - 8 } & $\begin{array}{l}\text { Ammonium } \\
\text { Nitrate (AN) }\end{array}$ & 6.74 & 7.76 & 8.91 & 36.65 & 45.65 & 52.41 \\
\cline { 2 - 8 } & $\begin{array}{l}\text { Ammonium } \\
\text { Sulfate (AS) }\end{array}$ & 6.80 & 7.97 & 9.06 & 39.11 & 44.88 & 50.29 \\
\hline Giza 95 & Urea (U) & 6.24 & 7.31 & 8.33 & 38.71 & 43.00 & 51.94 \\
\cline { 2 - 8 } & $\begin{array}{l}\text { Ammonium } \\
\text { Nitrate (AN) }\end{array}$ & 6.63 & 7.50 & 9.00 & 39.44 & 43.12 & 50.90 \\
\cline { 2 - 8 } & $\begin{array}{l}\text { Ammonium } \\
\text { Sulfate (AS) }\end{array}$ & 6.77 & 7.63 & 9.13 & 39.40 & 43.22 & 51.71 \\
\hline
\end{tabular}

\subsubsection{Wax\%, Sugar\% and Ash.}

The typical mature cotton fiber contains about $0.6 \%$ wax where most of the values reported in the literature ranged between 0.4 and $1.3 \%$ (Rollins, 1965). The differences in fiber content of the major chemical constituents may
Egyptian cotton . However, Giza 83 variety attained the highest value of total reducing sugar, while Giza 80 gave the highest values of both wax and ash content. (Amal, 2003). The pedegree of Giza 95 was: Giza 95 (Giza83 $\times$ $($ Giza75×5844) × Giza 80). (Table (6). 
Heba A. Mohamed and Rania M. Abdel- Twab...................................................

Table (6): Wax, sugar and Ash of cotton fiber as affected by the interaction among cultivars, nitrogen sources and chemical treatments.

\begin{tabular}{|c|c|c|c|c|c|c|}
\hline \multicolumn{2}{|c|}{ Treatments } & \multicolumn{3}{|c|}{ Control } & \multicolumn{2}{|c|}{$\mathbf{K} / \mathbf{S}$} \\
\hline \multirow{2}{*}{$\begin{array}{l}\text { Cultivars } \\
\text { (A) }\end{array}$} & \multirow{2}{*}{$\begin{array}{c}\text { Nitrogen } \\
\text { Sources (B) }\end{array}$} & \multicolumn{3}{|c|}{ Chemical Treatments (C) } & \multicolumn{2}{|c|}{ Chemical Treatments $(C)$} \\
\hline & & Wax\% & Sugar \% & Ash\% & Scouring & Mercerization \\
\hline \multirow[t]{3}{*}{ Giza 93} & Urea (U) & 1.58 & 0.13 & 0.993 & 3.1 & 4.2 \\
\hline & $\begin{array}{l}\text { Ammonium } \\
\text { Nitrate (AN) }\end{array}$ & 1.50 & 0.12 & 0.992 & 4.5 & 5.1 \\
\hline & $\begin{array}{l}\text { Ammonium } \\
\text { Sulfate (AS) }\end{array}$ & 1.60 & 0.13 & 0.991 & 4.8 & 5.7 \\
\hline \multirow[t]{3}{*}{ Giza 94} & Urea (U) & 1.60 & 0.16 & 0.993 & 1.2 & 2.8 \\
\hline & $\begin{array}{l}\text { Ammonium } \\
\text { Nitrate (AN) }\end{array}$ & 1.70 & 0.16 & 0.990 & 1.4 & 3.0 \\
\hline & $\begin{array}{l}\text { Ammonium } \\
\text { Sulfate (AS) }\end{array}$ & 1.66 & 0.17 & 0.992 & 3.0 & 3.4 \\
\hline \multirow[t]{3}{*}{ Giza 95} & Urea $(\mathbf{U})$ & 0.80 & 0.14 & 0.996 & 1.9 & 2.6 \\
\hline & $\begin{array}{l}\text { Ammonium } \\
\text { Nitrate (AN) }\end{array}$ & 1.91 & 0.14 & 0.991 & 2.5 & 3.7 \\
\hline & $\begin{array}{l}\text { Ammonium } \\
\text { Sulfate (AS) }\end{array}$ & 1.70 & 0.15 & 0.994 & 2.8 & 3.9 \\
\hline \multicolumn{2}{|c|}{ L.S.D0.05 $(\mathrm{A} \times \mathrm{B} \times \mathrm{C})$} & 0.56 & N.S & 0.33 & & .23 \\
\hline
\end{tabular}

\subsubsection{Cellulose Crystallinity \%。}

Data in Table (7) cleared that there were significant differences among the three genotypes, nitrogen sources and chemical treatment in the ratio of amorphous regains, whereas Giza 93 fertilized with ammonium sulphate with control chemical treated was superior in toughness while Giza 93 with ammonium sulphate with scouring chemical treated was superior in the ratio of amorphous regains, and Giza 93 with ammonium sulphate and mercerization treated scored the best value in the ratio of amorphous regains. The results show that, scouring and mercerization process caused a decrease in cellulose crystallinity \%. It could be noticed that, mercerization decreased, in general, the crystallinity \% of cotton fibers. This reduction results lead to increasing the ratio of amorphous regains, (Morton and Hearle, 1975).

Table( 7): cellulose crystallinity of cotton fiber as affected by the interaction among cultivars, nitrogen sources and chemical treatments.

\begin{tabular}{|c|c|c|c|c|c|c|c|}
\hline \multicolumn{2}{|c|}{ Treatments } & \multirow{2}{*}{\multicolumn{3}{|c|}{$\begin{array}{c}\text { Amor. } \\
\text { Chemical Treatments }(C)\end{array}$}} & \multirow{2}{*}{\multicolumn{3}{|c|}{$\begin{array}{c}\text { Cryst. } \\
\text { Chemical Treatments }(\mathrm{C})\end{array}$}} \\
\hline \multirow{2}{*}{$\begin{array}{c}\text { Cultivars } \\
\text { (A) }\end{array}$} & \multirow{2}{*}{$\begin{array}{c}\text { Nitrogen } \\
\text { Sources }(B)\end{array}$} & & & & & & \\
\hline & & Control & Scouring & Mercerization & Control & Scouring & Mercerization \\
\hline \multirow[t]{3}{*}{ Giza 93} & Urea (U) & 8.6 & 15.5 & 29.7 & 91.4 & 85.5 & 70.3 \\
\hline & $\begin{array}{l}\text { Ammonium } \\
\text { Nitrate (AN) }\end{array}$ & 7.8 & 13.9 & 29.2 & 92.2 & 86.2 & 71.0 \\
\hline & $\begin{array}{l}\text { Ammonium } \\
\text { Sulfate (AS) }\end{array}$ & 6.9 & 12.1 & 28.5 & 91.1 & 86.1 & 71.5 \\
\hline \multirow[t]{3}{*}{ Giza 94} & Urea (U) & 10.0 & 18.9 & 33.3 & 90.0 & 81.1 & 69.7 \\
\hline & $\begin{array}{l}\text { Ammonium } \\
\text { Nitrate (AN) }\end{array}$ & 9.2 & 18.1 & 31.1 & 90.8 & 81.9 & 68.9 \\
\hline & $\begin{array}{l}\text { Ammonium } \\
\text { Sulfate (AS) }\end{array}$ & 8.6 & 17.3 & 30.4 & 90.4 & 84.7 & 68.6 \\
\hline \multirow[t]{3}{*}{ Giza 95} & Urea $(\mathbf{U})$ & 10.7 & 16.9 & 36.3 & 89.3 & 84.1 & 66.7 \\
\hline & $\begin{array}{l}\text { Ammonium } \\
\text { Nitrate (AN) }\end{array}$ & 11.1 & 14.6 & 35.7 & 89.9 & 84.4 & 66.3 \\
\hline & $\begin{array}{l}\text { Ammonium } \\
\text { Sulfate (AS) }\end{array}$ & 10.4 & 19.0 & 34.5 & 89.6 & 81.1 & 66.5 \\
\hline \multicolumn{2}{|c|}{ L.S.D0.05 $(\mathrm{A} \times \mathrm{B} \times \mathbf{C})$} & \multicolumn{3}{|c|}{0.49} & \multicolumn{3}{|c|}{ N.S } \\
\hline
\end{tabular}


The chemical structure and microstructure of cotton fibers have significant influence on the properties of the fibers, as cotton fibers consist of almost cellulose which has a crystalline/amorphous micro-fiber structure. Elementary fibrils are built from ordered crystallites and less-ordered amorphous regions statistically alternated along the fiber. The ratio between crystalline and amorphous areas strongly influences the characterizes stics of cotton fiber (Yatsu et al.,1986; Nikolić et al., 2011).

\section{CONCLUSION}

Nitrogen is the most essential nutrient needed to optimized crop yield and economic return. However, $\mathrm{N}$ use efficiency of most fertilizer is just 30 to $50 \%$. The different cotton varieties showed differential response to chemical treatments as mercerization process is an important operation which causes disorientation of non-crystalline chains and, therefore, influences the crystallinity proportion decrease, together with the amorphous regions increase and dyeability of dyeing process. It is considered as an irreversible reaction. These results are very important for the cotton breeder and the finishing textile industry.

\section{REFERENCES}

AATCC (Technical Manual of American Association of Textile Chemistry and Colorist (1994). Test method 74 to measure ash content.

Abdel-Aziz M. A. (2001). Influence of fiber maturity on technological and chemical fiber properties of raw and mercerized Egyptian cultivars. J. Appl.Sci., 16 (6): 129-140.

Abdel-Aziz Heba M. (2005). Effect of gammairradiation and chemical modification treatments on technological and chemical properties of some Egyptian cotton cultivars. M.Sc. Thesis. Cairo Unvi., Egypt. Pp: 150 .

Abdel-Aziz Heba M. (2015). Biochemical studies on some textiles of Egyptian cotton varities.Ph.D. Thesis., Cairo Unvi., Egypt. Pp:157.

Ahmed N. T. (1981). Studies on fiber structural weak points in Egyptian cotton and their potential strengthening by chemical treatments. Ph.D. Thesis, Fac. Agric. Cairo Unvi., Egypt.
Al-Ashwat A. A. (1974). Effect of sodium Hydroxide and Hydrogen peroxide on the structural and mechanical properties of the Egyptian cotton fiber and yarn. Ph.D. Thesis, Fac. of Agri., Cairo Unvi., Egypt .

Alliance Organics LLP (2014). Developed and Managed by IndiaMART InterMESH. http:// www.dyespigments. net/ direct-dyes. Html.

Amal M. S. (2003). Differences in fiber contents of the major chemical constituents due to variety and grade of some Egyptian cotton. Egypt. J. Agric. Res., 81(2): 659-670.

A.S.T.M. America Society for Testing and Materials (1976). Desigation D; 1967, 2818-1982.

Brady N. C. and Weil R.R. (2008). Practical nutrient management. The nature and properties of soils. In: V.R. Anthony (ed.) Pearson Prentice Hall, Upper Saddle River, NJ., USA. pp. 708-712.

Collier A. M. (1974). In a Hand Book of textiles. Production of the natural fibers of vegetable origin. Chapter(2): New York,USA. p: 8-16.

Conrad C.M. (1944). Determination of wax in cotton fiber. A new alcohol extraction method. Insdut. and Engin. Chem. 16 (12): 745-748.

De Boer J. J. (1973). The spiral angle and orientation of swollen and stretched single cotton fibers and their relation to fiber tenacity. Text. Res. J., 43: 141-145.

Dexter B. Watts G. Brett Runion, Katy W. Smith Nannenga, and S., Allen S., Torbert (2014). Enhanced-efficiency fertilizer effects on cotton yield and quality in the coastal plains. Agron., j.106(2): 745-752.

Grover E. B. and Hamby, D. S. (1960). Hand Book of Textile Testing and Quality Control. Textile Book Publishers, New York. U.S.A.

Gomez K. A. and Gomez A. A. (1984). Statistical procedures for agricultural research. John Wiley and sons, NewYork, 680p.

Havlin J.L., Beaton J.D., Tisdale Tisdale S.L. and Nelson W.L. (2005). Nitrogen. pp. 97157. In: D. Yarnell et al. (ed.) Soil Fertility and Fertilizers: An Introduction to Nutrient Management. 7th ed. Pearson Education Inc., Upper Saddle River, NJ.

Hebeish A., Mashoor R.and Kamel M. (1970). Effect of pretreatments on some physical and chemical properties of cotton cellulose 
before and after dyeing during irradiation part1: effect of pretreatment on the photodegradation of cotton. American Dyestuff Reporter, 60: 39-42.

James M. B. (2014). The Response of Cotton (Gossypium hirsutum L.) to slow release foliar fertilization and the effect of environment on absorption. M.Sc. Thesis in Crop, Soil, and Environmental Sciences. Univ. of Arkansas, Fayetteville, Ark., USA.

Kamal M.M. (1980). Effect of blending and some chemical treatments on lint and yarn properties of some Egyptian cotton cultivars. Ph.D. Thesis, Fac. of Agric. Cairo Univ., Egypt.

Lawson R., Ramey H. H. Jr. and Jones J. B. (1979). Relation of cotton fiber maturity and strength uniformity to change in theacity with mercerization. Text. Res. J., 49(8): 433-437.

Mengel K. and Kirkby E.A. (1987). Nitrogen. In: Principles of Plant Nutrition. $4^{\text {th }}$ ed. pp. 347-384. International Potash Institute, Bern, Switzerland.

Morton W. E. and Hearle J. W. S. (1975). Physical properties of textile fibers. Photolithography and bound in Great Britain. The Pitman Press: 265-275.

Nikolić T., Kostić M., Praslalo J., Petronijević Z. and Śkundrić P. (2011). Sorption properties of periodate oxidized cotton, Chem Ind Chem Eng., 17(3):367-374.

Orr R. S., Buryes A. W., Anderson F. R., and Grant J. N. (1959). Physical properties of mercerized and decrystallized cottons. Part I: Effect of swelling solution on fibers and yarns. Text. Res. J., 29: 349-355.

Patel B. H. (2005). Improved dyeability of cotton by chemical modification. The Indian Textile J. Vol.No(1 January): 41-46.
Ras C. P. (1963). A new theory of mercerization. Tex. Res. J., 29: 386-387.

Rollins M. L. (1965). The cotton fiber. Chapeter3 (Pp44-81) In: American Cotton And book. (Vol.1).

Schwartassek K. (1954). Faserforsh. Textiletech., 7, 477.

Shereen O. Bahhlool and Heba A. Mohamed (2019). Dyeing properties of Egyptian cotton fibers treated with liquid ammonia. Egypt. J. Appl. Sci., 34 (1): 13-24.

Smil V. (2001). Enrichng the Earth. MIT Press, Cambridge, MA, USA.

Smith F. G., Hamilton M. A., Robers J. K. and Dubois P.A. (1956). Calorimetric method for determination of sugar related substances. Anal. Chem. 28:350.

Snedcor D. M. and Cochran W. G. (1981). Statistical methods. College press, Ames, Iowa, U.S.A.

Troman E. R. (1984). Vat dyes in Dyeing and Chemical Technology of textile fibers, $1^{\text {st }}$ and $6^{\text {th }}$ Ed., Charles Griffin and Co.Pp:407433. London.

Torbert (2014). Enhanced-Efficiency feritilizer Effects on cotton Yield and Quality in the Coastal Plains. Agron, J. 106 (2): 745-752.

Valentine I. (1954). Moisture regain and accessibility of cellulose derivatives. Tex. Res. J., 124: 6720-6721.

Wang J. H., Freeman S. and Glaxto L. D. (2007). Color Technology, (123): 39-45.

Wimonrat S., Preechaya R., Wanvichit P. and Siwapol P. (2009). Effect of enzymatic treatment on the dyeing of pineapple leaf fibers with natural dyes. Sci. Asia, 35: 3136.

Yatsu L. Y., Calamari T. A. and Benerito R. R. (1986). Conversion of cellulose-I to stable cellulose-III. Text Res. J., 56: 419-424. 


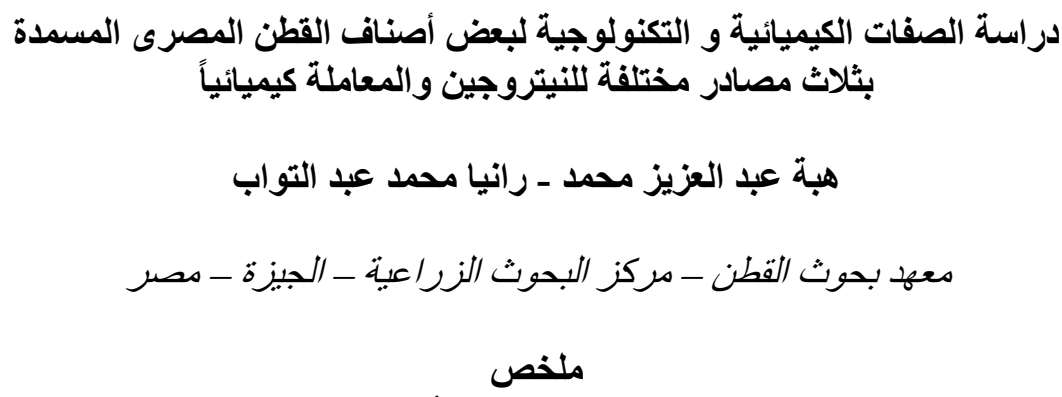

يدرس هذ البحث تقييم الصفات التكنولوجية و الكيميائية لبعض ألياف القطن المصرى المسمدة بثلاث مركبات مختلفة

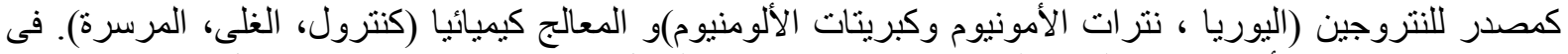

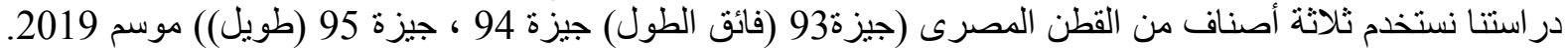

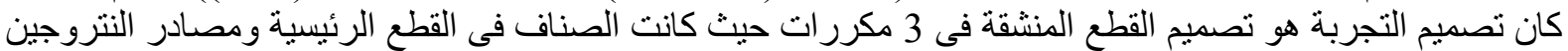

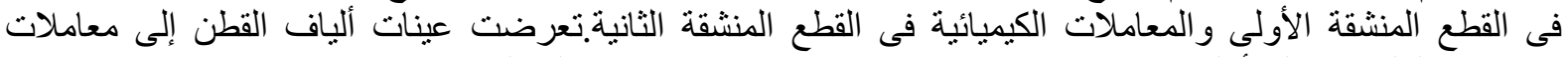

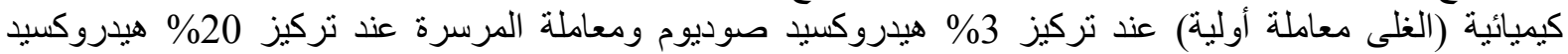

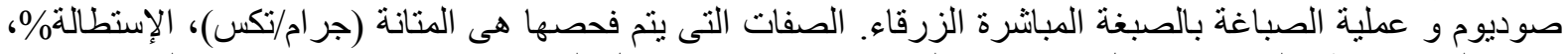

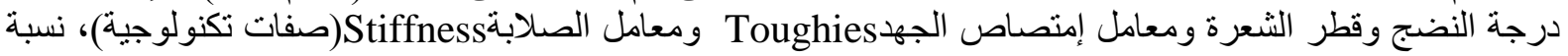
السكر \%\% ، نسبة الثمع \%، نسبة الرماد\%\%، الرطوبة المكتسبة \%، درجة النشاط الكيميائى \%، درجة عمق اللون (K/S) (صفات كيميائية).

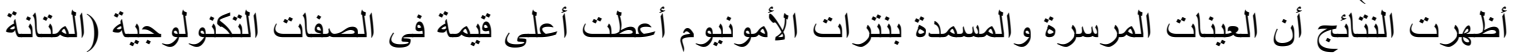

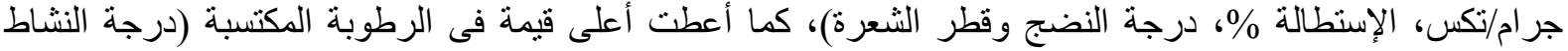

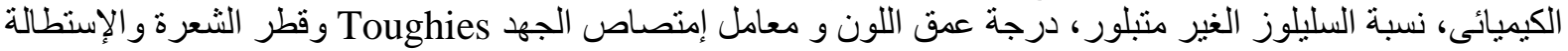

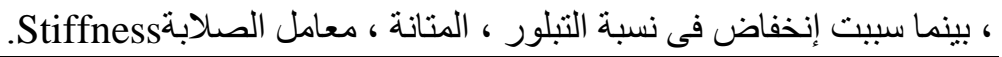

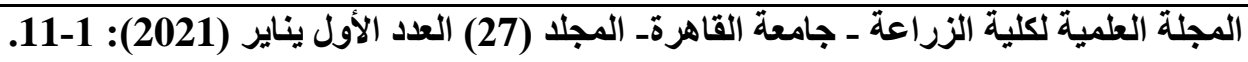

